\title{
Deskripsi Kemampuan Komunikasi Matematis Siswa SMK berdasarkan Tingkat Kepercayaan Diri
}

\author{
Alimuddin ${ }^{1, \text { a) }}$, Ahmad Talib ${ }^{1, b)}$, dan Gustikasari Amin ${ }^{1, \mathrm{c})}$ \\ ${ }^{1}$ Jurusan Matematika, Fakultas MIPA, Universitas Negeri Makassar \\ a) alimuddin@unm.ac.id \\ b) matalibunm@yahoo.com \\ c) gustikasariamin25@gmail.com
}

\begin{abstract}
Abstrak. Penelitian ini bertujuan untuk mendeskripsikan kemampuan komunikasi matematis siswa berdasarkan tingkat kepercayaan diri pada materi statistika. Subjek penelitian terdiri atas 3 orang siswa kelas XI SMK di kabupaten Kabupaten Soppeng, yaitu 1 siswa dengan kepercayaan diri tinggi (KDT), 1 siswa dengan kepercayaan diri sedang (KDS) dan 1 siswa dengan kepercayaan diri rendah (KDR). Hasil penelitian menunjukkan bahwa (1) KDT mengomunikasikan ide matematisnya dalam bentuk diagram lebih baik dibanding subjek lain. KDT menganalisis dan menjelaskan ide matematis secara lebih rinci dan detail. KDT menulis penyelesaian serta memberikan alasan yang jelas dari pernyataan yang ungkapkannya (2) KDS mampu mengomunikasikan ide matematisnya ke dalam bentuk diagram, namun kurang mampu menentukan interval nilai yang digunakan dengan tepat. KDS mampu menganalisis dan mampu menjelaskan ide matematis secara lisan, namun tidak mampu menjelaskan strategi penyelesaian secara lisan. KDS kurang mampu menulis penyelesaian dengan informasi yang lengkap, namun sudah maтрu memberikan alas an dari sebuah pernyataan yang diungkapkan; (3) KDR mampu mengomunikasikan ide matematisnya ke dalam bentuk diagram, namun kurang mampu menentukan interval nilai yang digunakan dengan tepat. KDR kurang mampu menganalisis ide matematis dan tidak mampu menjelaskan strategi dalam membuat diagram. KDR sudah mampu menulis penyelesaian namun tidak mampu memberikan alasan terhadap pernyataan yang diungkapkan.
\end{abstract}

Kata Kunci: Kemampuan komunikasi matematis, kepercayaan diri

\begin{abstract}
The purpose of the research was to describe students' mathematical communication abilities based on their levels of self-confidence in topic of statistics. The subjects were 3 students of class XI SMK in Soppeng. They were one student with high self-confidence (KDT), one student with medium selfconfidence (KDS) and one student with low self-confidence (KDR). The results showed that (1) KDT communicate mathematical ideas in diagrams better than others. KDT analyze and explain mathematical ideas in detail. KDT could write and give clear reasons; (2) KDS could communicate mathematical ideas in diagrams, but in determining the interval of values used, KDS could not do it correctly. KDS could analyze and explain ideas orally but unable to explain strategies used in making diagrams orally. KDS could not answer with complete information but could provide reasons; (3) KDR could communicate mathematical ideas in diagrams, but in determining the interval of values used, KDR could not do it correctly. KDR was less able to analyze mathematical ideas and unable to explain the strategies used in making diagram. KDR had been able to write answer but not able to give reasons.
\end{abstract}

Keywords: Mathematical communication abilities, self-confidence 


\section{PENDAHULUAN}

Komunikasi adalah suatu proses di mana terjadi penyampaian pesan dari sumber kepada penerima pesan dengan maksud untuk mempengaruhi penerima pesan (Lunenburg, 2010; Harapan dan Ahmad, 2016; Tinungki, 2015). Komunikasi bertujuan untuk membagikan ide atau gagasan, mendiskusikan suatu ide atau gagasan serta untuk membangun ide atau gagasan yang lebih mendalam lagi. Kemampuan komunikasi yang baik sangat dibutuhkan di setiap bidang kehidupan. Oleh karena itu, kemampuan komunikasi harus dimiliki oleh setiap individu.

National Council of Teachers of Mathematics (NCTM) (2000) menjelaskan bahwa kemampuan dasar yang harus dimiliki oleh siswa yang merupakan standar kemampuan matematika yaitu pemecahan masalah (problem solving), penalaran (reasoning), komunikasi (communication), koneksi (connection) dan representasi (representation). Dalam standar isi satuan pendidikan dasar dan menengah mata pelajaran matematika (Peraturan Manteri Pendidikan Nasional No. 22 Tahun 2006 tanggal 23 Mei 2006 tentang Standar Isi) menyebutkan salah satu tujuan dari pembelajaran matematika, yaitu supaya siswa memiliki kemampuan mengomunikasikan gagasan dengan simbol, tabel, diagram, maupun media lainnya untuk memperjelas keadaan atau masalah.

Kemampuan komunikasi dalam ilmu matematika disebut komunikasi matematis. Komunikasi matematis terdiri atas dua, yaitu komunikasi matematis lisan dan komunikasi matematis tulisan (Hodiyanto, 2017). Komunikasi matematis adalah sebuah upaya untuk menyampaikan dan merefleksi ide atau gagasan matematis yang dimiliki, mendiskusikan ide atau gagasan dengan cara saling bertukar ide atau gagasan terkait matematika baik secara lisan maupun tulisan (NCTM, 2000; Tupa, 2015; Fachrurazi, 2011; Prayitno, Suwarsono dan Siswono, 2013). Siswa yang memiliki kemampuan komunikasi matematis akan mampu menyalurkan ide matematis mereka mampu membuat representasi yang beragam. Hal ini akan lebih memudahkan mereka dalam menemukan alternatif-alternatif penyelesaian yang berakibat pada meningkatnya kemampuan menyelesaikan permasalahan matematika siswa (Qohar, 2011). Selain itu, melalui komunikasi matematis juga dapat membantu siswa dalam mengorganisasikan berpikir matematisnya secara lisan maupun tulisan dan siswa juga mampu memberikan respon terhadap materi pelajaran dengan baik (Yuliani, Agostanto dan Winanti, 2018).

Berdasarkan hasil penilaian PISA 2018 (Schleicher, 2019) menunjukkan bahwa skor yang diperoleh oleh Indonesia pada bidang matematika adalah 379 dan berada pada posisi ke 72 dari 78 negara yang berpartisipasi. Hasil ini masih tergolong rendah dibandingkan Negara-negara tetangga Singapura yang memperoleh skor 569 dan Malaysia dengan skor 440. Salah satu kemampuan matematis yang tergolong rendah yaitu kemampuan komunikasi matematis siswa (Noviyana, Dewi dan Rochmad, 2019). Ini dikarenakan masih rendahnya kemampuan siswa dalam menyajikan ide-ide matematis ke dalam bentuk simbol, grafik maupun tabel. Hal ini sejalan dengan hasil penelitian yang dilakukan oleh Aminah, Wijaya dan Yuspiyati (2018) yang menyatakan bahwa kemampuan komunikasi matematis menghubungkan benda nyata, gambar dan diagram ke dalam ide matematika tergolong rendah.

Kesulitan siswa dalam menyampaikan pendapat ini bisa diakibatkan oleh kepercayaan diri yang rendah. Siswa merasa khawatir berpendapat karena merasa pendapatnya akan salah. Seseorang yang kurang percaya diri lebih banyak memilikirkan hal-hal negatif dari sesuatu yang akan dilakukan. Sehingga mereka lebih memiliki diam meskipun sudah ada ide di pikirannya. Hal tersebut merupakan penghambat bagi mereka dalam mengemukakan pendapat dengan baik. Akibatnya proses komunikasi matematis tidak terlaksana dengan baik. Kepercayaan diri merupakan sebuah keyakinan atas kemampuan yang dimiliki, keyakinan untuk melakukan tindakan tanpa adanya rasa khawatir, keyakinan untuk melakukan tindakan demi mencapai impian yang diinginkan (Akbar, Diniyah, Akbar, Nurjaman dan Bernard, 2018; Sheldrake, 2015; Rizqi, Suyitno dan Sudarmin, 2016; Rejeki, 2019). 
Berdasarkan permasalahan tersebut, perlu digali lebih mendalam tentang kemampuan komunikasi matematis siswa yang ditinjau dari tingkat kepercayaan diri. Penelitian ini bertujuan untuk mendeskripsikan kemampuan komunikasi matematis siswa dengan kepercayaan diri yang dimiliki siswa. Terdapat 3 kategori kepercayaan diri yang akan diteliti yaitu kategori tinggi, sedang dan rendah. Adapun indikator kemampuan komunikasi matematis yang digunakan dalam penelitian ini antara lain: 1) Kemampuan menyajikan permasalahan ke dalam bentuk gambar, tabel, atau diagram; 2) Kemampuan menganalisis dan menjelaskan ide matematis dan strategi penyelesaian; 3) Kemampuan menulis penyelesaian serta memberikan alasan.

\section{METODE PENELITIAN}

Jenis penelitian ini adalah deskripsi kualitatif. Subjek penelitian adalah siswa kelas XI dari salah satu SMK Negeri yang ada di Kab. Soppeng. Pemilihan subjek berdasarkan pada skor hasil angket sehingga diperoleh kategori kepercayaan diri tinggi, sedang dan rendah. Setiap kategori dipilih 1 subjek untuk dijadikan sebagai fokus penelitian.

Teknik pengumpulan data yang dilakukan dalam penelitian ini terdiri atas 3 teknik. Pertama, pemberian angket dengan menggunakan instrumen angket kepercayaan diri. Kedua, pemberian tes tertulis dengan instrumen tes kemampuan komunikasi matematis siswa. Ketiga, melakukan wawancara dengan menggunakan instrumen peodman wawancara.

Analisis data yang dilakukan terdiri atas beberapa langkah. Pertama, hasil tes yang telah dikerjakan oleh subjek di reduksi yaitu dengan memilih data-data penting saja. Selanjutnya, data yang telah dipilih diberikan kode. Adapun aturan pengkodean data dapat dilihat pada tabel 1.

TABEL 1 Aturan Pengkodean Hasil Pekerjaan Subjek

\begin{tabular}{cl}
\hline Urutan Digit & \multicolumn{1}{c}{ Keterangan } \\
\hline Digit Pertama & "S" menyatakan subjek dan "P" menyatakan peneliti \\
Digit Kedua & Menyatakan subjek ke berapa \\
Digit Ketiga & Menyatakan jenis pengumpulan data ("T" atau "W") \\
Digit Keempat & Menyatakan nomor soal ("1" untuk soal a, "2" untuk soal b, "3" \\
& untuk soal c dan "4" untuk soal d) \\
Digit Kelima & Menyatakan urutan petikan jawaban. \\
\hline
\end{tabular}

Setelah data diberikan kode, data dipaparkan berdasarkan kategori masing-masing. Adapun kategori yang dimaksud mengacuh pada indikator kemampuan komunikasi matematis. Selanjutnya melakukan validasi data untuk mengecek konsistensi data. Validasi data menggunakan triangulasi teknik yaitu dengan mengecek data kepada sumber yang sama namun dengan dua teknik yang berbeda yaitu tes dan wawancara.

\section{HASIL DAN PEMBAHASAN}

Sebelum subjek diberikan tes kemampuan komunikasi matematis, peneliti membagikan angket kepercayaan diri kepada calon subjek. Persentase hasil angket yang telah diisi oleh siswa kelas XI terdapat pada Gambar 1. Calon subjek yang diberikan angket kepercayaan diri berjumlah 18 orang siswa. Adapun hasil dari angket kepercayaan diri yang telah dikerjakan siswa dapat dilihat pada Gambar 1. Siswa yang memiliki kepercayaan diri tinggi berjumlah 12 orang, siswa yang memiliki kepercayaan diri sedang berjumlah 4 dan siswa yang memiliki kepercayaan diri rendah berjumlah 2 orang. Setelah dikelompokkan berdasarkan kategori, masing-masing kategori diambil 1 siswa untuk diberikan tes kemampuan komunikasi matematis lalu kemudian diwawancara. 


\section{Hasil Angket}

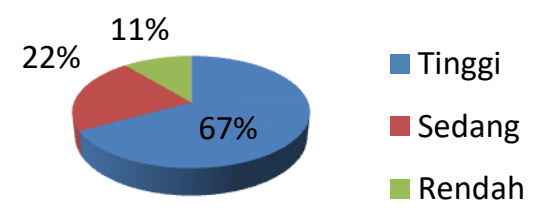

GAMBAR 1 Persentase Tiap Kategori berdasarkan Hasil Angket

Berdasarkan hasil tes dan wawancara masing-masing subjek:

Subjek dengan Kepercayaan Diri Tinggi

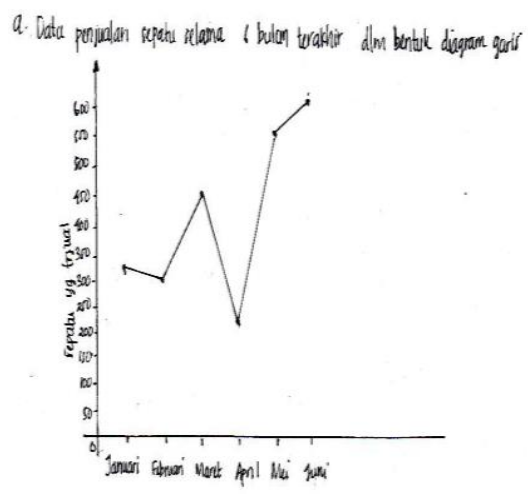

(a)

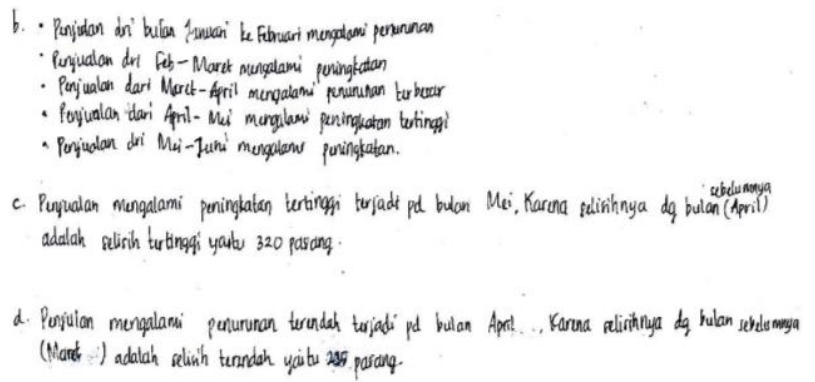

(b)

GAMBAR 2 Hasil Tes Subjek dengan Kepercayaan Diri Tinggi

Berdasarkan Gambar 2, terlihat bahwa subjek telah membuat diagram garis yang sesuai dengan data pada table yang diberikan. Subjek menentukan letak setiap variabel pada sumbu yang tepat, yaitu variable "jumlah sepatu yang terjual" pada sumbu-y dan variabel "bulan" pada sumbu-x. Pada penentuan interval nilai pada sumbu-y, subjek menggunakan nilai-nilai dengan interval yang sama, yaitu 50. Subjek menuliskan peningkatan dan penurunan yang terjadi setiap bulannya serta kapan peningkatan tertinggi terjadi dan kapan penurunan terbesar terjadi. Subjek menulis alasan kenapa penjualan tertinggi terjadi pada bulan Mei yaitu dengan melihat selisih antara penjualan pada bulan April dan penjualan pada bulan Mei. Begitupun dengan alasan kenapa penurunan terendah terjadi pada bulan April, subjek melihat selisih penjualan di bulan Maret dan April.

\section{TRANSKRIP 1}

P-W13: $\quad$ Maksudnya, bagaimana langkah-langkah yang Anda lakukan sewaktu membuat diagram ini?

S1-W13: $\quad$ Oh pertama kak, ku perhatikan dulu tabelnya lalu ku urutkan nilai-nilainya dari yang terkecil ke terbesar lalu ku tentukan intervalnya sumbu y, lalu kuisi mi sesuai dengan nilai untuk tiap bulannya kak.

P-W21 : Baiklah selanjutnya, informasi apakah yang bisa didapat dari diagram yang Anda buat?

S1-W21: Diagram ini menunjukkan adanya penurunan dan peningkatan penjualan sepatu kak. Mengalami penurunan sebanyak $2 x$ dan mengalami peningkatan selama $3 x$.

$P-W 41$ : $\quad$ Kalau untuk penurunan terendah bagaimana?

S1-W41 : $\quad$ Oh kalau itu kak pada bulan Maret ke April 
Berdasarkan petikan wawancara pada Transkrip 1, terlihat bahwa subjek mengetahui bahwa diagram yang dibuat menunjukkan adanya penurunan dan peningkatan penjualan (S1-W21). Subjek juga mengetahui bahwa berapa kali terjadi peningkatan dan berapa kali terjadi penurunan (S1-W21). Selain itu, subjek mengetahui kapan penjualan mengalami peningkatan paling tinggi dan kapan penjualan mengalami penurunan paling drastis (S1-W41). Subjek juga menjelaskan bagaimana langkah-langkah yang dilakukan dalam membuat diagram garis secara lisan (S1-W13).

\section{Subjek dengan Kepercayaan Diri Sedang}

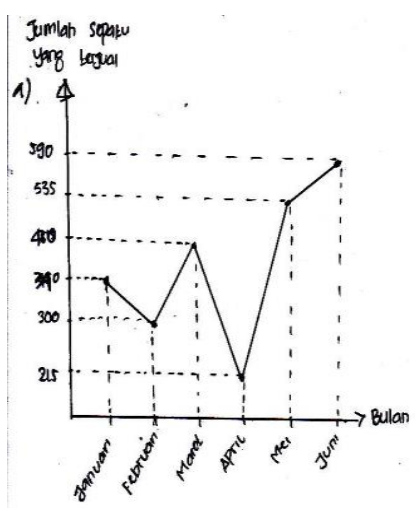

(a)

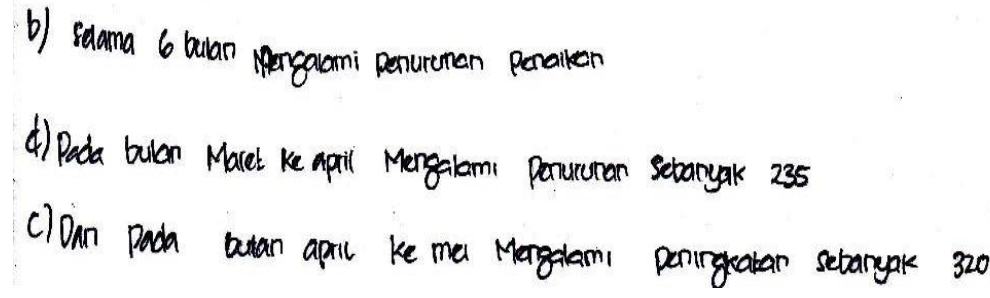

(b)

GAMBAR 3 Hasil Tes Subjek dengan Kepercayaan Diri Sedang

Berdasarkan Gambar 3, terlihat bahwa subjek menggambar diagram garis yang sesuai dengan data pada table yang diberikan. Subjek menentukan letak setiap variabel pada sumbu yang tepat. Namun pada penentuan interval yang digunakan, subjek menggunakan interval nilai yang berbeda-beda. Subjek tidak menggunakan interval yang sama melainkan langsung menggunakan nilai-nilai yang ada pada tabel.

Selain itu subjek hanya menuliskan "selama 6 bulan mengalami penurunan peningkatan"sebagai jawaban untuk soal yang meminta subjek menjelaskan informasi apa saja yang terdapat pada diagram. Subjek tidak menuliskan apa yang terjadi setiap bulannya, apakah penjualan mengalami penaikan atau penurunan. Subjek menuliskan pada bulan apa terjadi penaikan tertinggi dan pada bulan apa terjadi penurunan terbesar. Subjek mencantumkan alasan yang tepat bahwa peningkatan pada bulan April ke Mei adalah 320 dan penurunan penjualan pada bulan Maret ke April sebanyak 235.

\section{TRANSKRIP 2}

P2-W14 Bagaimana langkah-langkah yang Anda lakukan dalam membuat diagram ini?

S2-W14 Hmm.. langsungji kak ku gambar

P2-W25 Jadi intinya bagaimana?

S2-W25 Jadi pendapatannya perusahaan tidak stabil karena pendapatannya naik turun setiap bulannya.

P2-W31 Selanjutnya, pada bulan berapa penjualan mengalami peningkatan paling

S2-W31 April ke Mei

P2-W41 Kalau penurunan terendah pada bulan berapa?

S2-W41 Maret ke April kak

Berdasarkan petikan wawancara pada Transkrip 2, terlihat bahwa subjek mengetahui bahwa pendapatan dari perusahaan tidak stabil yang dikarenakan pendapatan yang naik turun setiap 
bulannya (S2-W25). Subjek juga mengetahui pada bulan berapa penjualan mengalami peningkatan tertinggi dan pada bulan berapa penjualan mengalami penurunan terbesar (S2-W31, S2-W41). Namun saat ditanya bagaimana langkah-langkah yang dilakukan dalam membuat diagram garis, subjek tidak mampu menjelaskannya secara lisan (S2-W14).

\title{
Subjek dengan Kepercayaan Diri Rendah
}

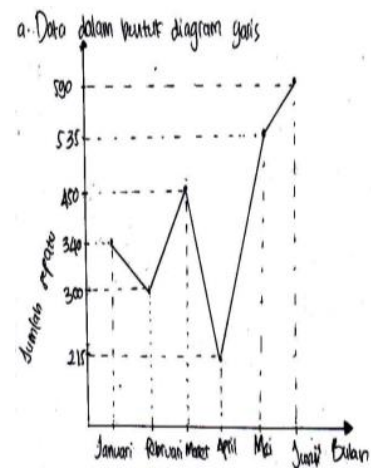

(a)

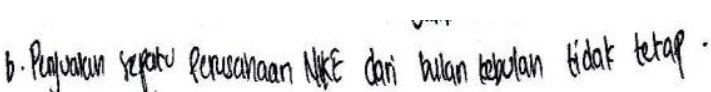

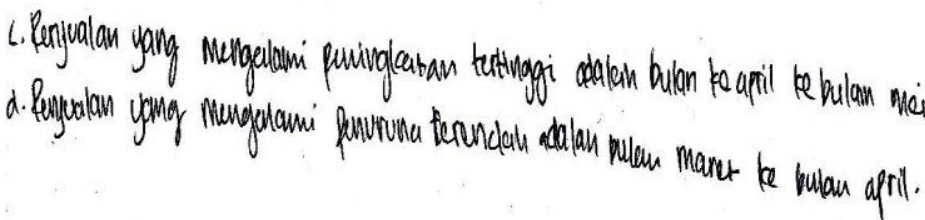

(b)

GAMBAR 4 Hasil Tes Subjek dengan Kepercayaan Diri Rendah

Berdasarkan Gambar 4, terlihat bahwa subjek membuat diagram garis yang sesuai dengan data pada table yang diberikan. Subjek menentukan letak setiap variabel pada sumbu yang tepat. Namun, pada penentuan interval pada nilai-nilai di sumbu-y, subjek menggunakan interval yang berbeda-beda. Subjek tidak menggunakan interval yang sama, namun langsung menulis nilainilai pada tabel.

Selain itu, subjek menuliskan bahwa penjualan sepatu di Perusahaan NIKE dari bulan ke bulan tidak stabil. Subjek tidak menuliskan bagaimana keadaan penjualan setiap bulannya dan langsung menyimpulkan bahwa penjualan tidak stabil. Subjek menuliskan bahwa kapan penjualan mengalami peningkatan tertinggi dan kapan penjualan mengalami penurunan terbesar. Akan tetapi, subjek tidak mencantumkan alasan kenapa penjualan pada bulan April ke Mei paling tinggi. Begitupun kenapa pada bulan Maret ke April penjualan mengalami penurunan paling besar.

\section{TRANSKRIP 3}

\author{
P3-W13 : Bagaimana langkah-langkah dalam membuat diagram ini? \\ S3-W13: $\quad$ Bagaimana di', langsung ji ku gambar kak \\ P3-W21 : $\quad$ Oke selanjutnya, apakah yang bisa didapat dari diagram ini? \\ S3-W21: $\quad$ Perubahan penjualan \\ P3-W22 : Bagaimana perubahannya? \\ S3-W22: $\quad$ Naik turun i garisnya kak \\ P3-W23 : $\quad Y a$, mana yang mengalami penaikan atau penurunan? \\ S3-W23: $\quad$ Bulan April ke Mei naik \\ P3-W24 : Jadi kira-kira berapa peningkatannya penjualan pada bulan April ke Mei? \\ S3-W24: $\quad$ Nda tau kak \\ P3-W31 : $\quad$ Baiklah, pada bulan berapa penjualan mengalami peningkatan paling tinggi? \\ S3-W31 : $\quad$ April ke Mei kak \\ P3-W41: Kalau penurunan terendah? \\ S3-W41 : $\quad$ Bulan Maret ke April kak
}

Berdasarkan petikan wawancara pada Transkrip 3, terlihat bahwa subjek mengetahui bahwa terdapat perubahan dalam penjualan yang ditandai dengan naik turunnya garis pada diagram (S3-W21, S3-W22). Subjek mengetahui kapan penjualan naik. Namun, saat ditanyai berapa kenaikan yang terjadi pada bulan April ke Mei, subjek tidak mampu menjawabnya (S3-W24). 
Subjek mengetahui kapan penjualan mengalami penaikan tertinggi dan kapan mengalami penurun terbesar (S3-W31, S3-W41). Saat ditanya bagaimana langkah-langkah dalam membuat diagram garis, subjek tidak mampu menjelaskan langkah-langkah yang dilakukannya dalam membuat diagram garis tersebut (S3-W13).

\section{KESIMPULAN}

Siswa yang memiliki kepercayaan diri tinggi mampu mengomunikasikan ide matematisnya dalam bentuk gambar, tabel atau diagram lebih baik daripada siswa dengan kepercayaan diri sedang maupun siswa dengan kepercayaan diri rendah. Hal ini terlihat dari kemampuan siswa dalam menggambar diagram dengan tepat serta mampu menjelaskan strategi dalam membuat diagram secara lisan. Siswa dengan kepercayaan diri tinggi mampu menganalisis dan menjelaskan ide-ide matematis secara lebih rinci dan detail. Siswa dengan kepercayaan diri tinggi mampu menulis penyelesaian serta memberikan alas an yang jelas dari setiap pernyataan yang diungkapkan.

Siswa yang memiliki kepercayaan diri sedang mampu mengomunikasikan ide matematisnya ke dalam bentuk gambar, tabel atau diagram, namun kurang mampu menentukan interval nilai yang digunakan dengan tepat. Siswa dengan kepercayaan diri sedang mampu menganalisis dan mampu menjelaskan ide-ide matematis secara lisan, namun tidak mampu menjelaskan strategi penyelesaian secara lisan. Siswa dengan kepercayaan diri sedang kurang mampu menulis penyelesaian dengan informasi yang lengkap, namun sudah mampu memberikan alasan dari sebuah pernyataan yang diungkapkan.

Siswa yang memiliki kepercayaan diri rendah mampu mengomunikasikan ide matematisnya ke dalam bentuk gambar, tabel atau diagram, namun kurang mampu menentukan interval nilai yang digunakan dengan tepat. Siswa dengan kepercayaan diri rendah kurang mampu menganalisis dan tidak mampu menjelaskan menjelaskan strategi yang dilakukan dalam membuat diagram. Siswa dengan kepercayaan diri rendah sudah mampu menulis penyelesaian namun tidak mampu memberikan alasan terhadap pernyataan yang diungkapkan.

\section{DAFTAR PUSTAKA}

Akbar, G.A.M., Diniyah, A.N., Akbar, P., Nurjaman, A., \& Bernard, M. (2018). Analisis Kemampuan Penalaran dan Self Confidence Siswa SMA dalam Materi Peluang. Journal On Education, 1(1). 14-21.

Aminah, S., Wijaya, T.T., \& Yuspriyati, D. (2018). Analisis Kemampuan Komunikasi Matematis Siswa Kelas VIII pada Materi Himpunan. Journal Cendekia: Jurnal Pendidikan Matematika, 1(1). 15-22.

Depdiknas. 2006. Permendiknas No. 22 Tahun 2006 tentang Standar Isi. Jakarta: Depdiknas.

Fachrurazi. (2011). Penerapan Pembelajaran Berbasis Masalah untuk Meningkatkan Kemampuan Berpikir Kritis dan Komunikasi Matematis Siswa Sekolah Dasar. Edisi Khusus.(1). 76-89.

Hodiyanto. (2017). Kemampuan Komunikasi Matematis dalam Pembelajaran Matematika. Jurnal AdMathEdu. 7(1). 9-17.

Harapan, E. \& Ahmad, S. (2016). Komunikasi Antarpribadi Perilaku Insani dalam Organisasi Pendidikan. Jakarta: RajaGrafindo Persada.

Lunenburg, F.C. (2010). Communication: The Process, Barriers, and Improving Effectiveness. Jurnal Schooling, 1(1). 1-11. 
National Council of Teacher Mathematics. (2000). Principles and Standards for School Mathematics. Reston. VA: NCTM.

Noviyana, I. N., Dewi, N. R., \& Rochmad. (2019). Analisis Kemampuan Komunikasi Matematis Siswa Ditinjau dari Self-Confidence. Prosiding Seminar Nasional Matematika. Semarang, Indonesia: Universitas Negeri Semarang.

Prayitno, S., Suwarsono, S., \& Siswono, T.Y.E. (2013). Komunikasi Matematis Siswa SMP dalam Menyelesaikan Soal Matematika Berjenjang Ditinjau dari Perbedaan Gender. Prosiding Seminar Nasional Matematika dan Pendidikan Matematika FMIPA UNY. Yogyakarta, Indonesia: Universitas Negeri Yogyakarta.

Qohar, A. (2011). Pengembangan Instrumen Komunikasi Matematika Untuk Siswa SMP. Makalah disajikan di Seminar Nasional Pendidikan Matematika LSM XIX. Yogyakarta, Indonesia : Universitas Negeri Yogyakarta.

Rejeki, Y. T. (2019). Analisis Kemampuan Komunikasi Matematis Siswa Kelas X SMK PGRI 2 Kediri Ditinjau dari Kepercayaan Diri Siswa pada Materi Sistem Persamaan Linear Dua Variabel (Skripsi). Universitas Nusantara PGRI Kediri, Kediri.

Rizqi, A.A., Suyitno, H., \& Sudarmin. (2016). Analisis Kemampuan Komunikasi Matematis Ditinjau dari Kepercayaan Diri Siswa melalui Blended Learning. Unnes Journal of Mathematics Education Research, 5(1). 17-23.

Schleicher, A. (2019). PISA 2018: Insights and Interpretations. https://www.oecd.org/pisa/PISA\%202018\%20Insights\%20and\%20Interpretations\%20F INAL\%20PDF.pdf. diakses pada tanggal 10 Desember 2019.

Shreldrake, R. (2015). Confidence as Motivational Expression of Interest, Unility, and Other Influences: Exploring Under-confidence and Over-convidence in Science Students at Secondary School. International Journal of Education Research, 76. 50-65.

Tinungki, G.M. (2015). The Role of Cooperative Learning Type Team Assisted Individualization to Improve the Students' Mathematics Communication Ability in the Subject of Probability Theory. Jurnal of Education and Practice, 6(32). 27-31.

Tupa, C. (2015). Pengaruh Model Pembelajaran Metakognitif terhadap Kemampuan Pemecahan Masalah dan Komunikasi Matematika pada Siswa SMPN 29 Makassar (Skripsi). Universitas Negeri Makassar, Makassar.

Yuliani, Agostanto, A., \& Winanti, K. (2018). Meningkatkan Kemampuan Komunikasi Matematis dan Kedisiplinan Siswa Kelas XI melalui Model PBL Materi Transformasi Geometri. Prisma, Prosiding Seminar Nasional Matematika (pp. 233-238). Semarang, Indonesia: Universitas Negeri Semarang. 